College of William \& Mary Law School William \& Mary Law School Scholarship Repository

1987

\title{
Federalism, Congress, the States and the Tenth Amendment: Adrift in the Cellophane Sea
}

William W. Van Alstyne

William \& Mary Law School

\section{Repository Citation}

Van Alstyne, William W., "Federalism, Congress, the States and the Tenth Amendment: Adrift in the Cellophane Sea" (1987). Faculty Publications. 741.

https://scholarship.law.wm.edu/facpubs/741

Copyright c 1987 by the authors. This article is brought to you by the William \& Mary Law School Scholarship Repository. 


\section{Duke Law Journal}

\begin{tabular}{l}
\hline VOLUME $1987 \quad$ NoveMBER \\
\hline \\
FEDERALISM, CONGRESS, THE STATES AND \\
THE TENTH AMENDMENT: ADRIFT IN \\
THE CELLOPHANE SEA
\end{tabular}

\section{WiLLIAM VAN ALSTYNE*}

Like Gaul, this essay is divided into three parts. The first two parts are adapted from a public address delivered at the Association of the Bar of the City of New York, as part of its Bicentennial series, in 1987. The third part was added later, originally as an Addendum Note.

The general subject was introduced by the moderator, Mr. Robert MacCrate, President of the Amerian Bar Association, who put the following question: "Where does the federalism of the Constitution stand today?" Professor Martha Field of the Harvard Law School presented a paper in first response. This paper then followed, and both will eventually appear with a number of other papers in book form, by Random House, some time in 1988 or 1989.

The metaphor of "the cellophane sea" in the title is borrowed from a dissent by Justice Frankfurter in United States v. Kahriger, demurring to the suggestion that enumerated-power nominalism is the sole test of federalism judicial review. I wholly agree with that dissent. The argument presented here is that the same kind of "illegitimate use" analysis Frankfurter invoked in the cellophane-wrapped tax case is, contrary to the conventional view, equally applicable to commerce power cases and every other enumerated power case as well.

At one point (toward the end of Part I), a hypothetical act of Congress is proposed. The reader is invited to choose between two mutually exclusive ways of resolving its constitutionality, as suggested alternatively, in Part II. Part III revisits the general problem of navigating the cellophane sea.

\footnotetext{
* Perkins Professor of Law, Duke University.
} 


\section{The Federalism of the Constitution}

\section{A.}

Federalism, generally, is that form of government "in which a union of states recognizes the sovereignty of a central authority while retaining certain residual powers of government."1 Constitutional federalism stands approximately midway between mere confederacy and the national state within which the paramount principle is that of democratic centralism. ${ }^{2}$

Federalism in our own constitutional order describes the division of political power by subject matter between the national government and the fifty states. It means that what the Constitution allocates (in its own words "delegates") to the national government to do, the national government may do as it likes, ${ }^{3}$ including maintaining massive armed forces, borrowing hugely on the national credit and declaring all out war. ${ }^{4}$ What the Constitution does not authorize the national government to do may still be done, but if it may-a matter, incidentally, the Constitution does not decide - still it may not be done by Congress. Rather, it must be done only on a more local basis, usually state by state. "Federalism" is thus an expression of constitutional shorthand respecting the vertical distribution of legislative jurisdiction in the United States.

The boundaries of federalism are partly determined in the first instance pursuant to the doctrine of enumerated powers: by specifying affirmatively what Congress is empowered to do-principally in the

1. American Heritage Dictionary 494 (2d College ed. 1982).

2. Compare our Constitution with the modern Constitution of the Union of Soviet Socialist Republics. KONST. SSSR [USSR Coustitution] art. 3, reprinted in BASIC DOCUMENTS ON THE SOVIET LEGAL SYSTEM 3, 5 (W. Butler ed. \& trans. 1983) ("[T] he Soviet state shall be structured in accordance with the principle of democratic centralism....").

3. Subject only to such restrictions as cut across its enumerated powers, e.g., restrictions found in article I, section 9, and those set forth in the Bill of Rights.

4. It has been insisted that "the Constitution ... is not a suicide pact." Kennedy v. MendozaMartinez, 372 U.S. 144, 160 (1963) (Goldberg, J.) (paraphrasing Terminiello v. Chicago, 337 U.S. 1, 37 (1949) (Jackson, J., dissenting)). In some respects, however, the Constitution does take that risk. In granting shape and substance to a national government that is unchecked in its power to put the entire country at risk through its combined foreign affairs and war powers, the Constitution is a gamble that that decision-to provide for a national government vested with such discretion-will not be disastrous in the end.

5. The Constitution is not the affirmative source of such power as each state government may or may not finally exercise; rather, those powers must, according to each state's own constitution, be justified within each state. The tenth amendment takes care to note this fact. It designates in whose favor (the states) powers not delegated to the United States are reserved, contingent, however, on each state government's ability to meet the affirmative demands of its owll constitution. See infra note 15 and accompanying text. 
enumerations provided in article I, section $8^{6}$-the Constitution provides what things may be done in the manner that Congress decides. When expressed in law within those specifications, the will of Congress controls subject only to such limitations as arise from the Bill of Rights and a few similar restrictions appearing elsewhere in the Constitution itself. ${ }^{7}$ Congress's entitlement to control in all such matters, moreover, is not left in doubt; it is expressly confirmed by the supremacy clause of article VI. Pursuant to that clause, every judge in every court-whether state or national-is bound by constitutional oath to give Congress's acts full faith and effect as controlling law, "any Thing in the Constitution or Laws of any State to the Contrary notwithstanding."

With respect to things not specified in this manner, however, what Congress may want-indeed, what substantial national majorities may want-generally does not matter in the least. No matter how large such majorities are nationally, they are not empowered on that account to have their way. ${ }^{9}$ Rather, it is the success and failure of appeals within

6. In addition, see the scattered provisions respecting affirmative powers vested in Congress in articles II through VI, as well as in the enabling sections of several subsequent amendments (e.g., thirteenth amendment, section 2; fourteenth amendment, section 5; fifteenth amendment, section 2; sixteenth amendment).

7. See, e.g., U.S. ConsT. art. I, $\$ 9$ (prohibiting Congress from suspending habeas corpus, enacting bills of attainder or ex post facto lavs, etc.).

8. U.S. CONST. art. VI, cl. 2.

9. The point was raised (albeit unavailingly) this last Term by Justice Marshall, dissenting in United States v. Salerno, 107 S. Ct. 2095, 2105 (1987). A majority of the Court sustained an unprecedented "preventive detention" act of Congress. But, as Justice Marshall noted:

The Constitution does not contain an explicit delegation to the Federal Government of the power to define and administer the general criminal law .... The majority nowhere identifies the constitutional source of congressional power to authorize the federal detention of persons whose predicted future conduct would not violate any federal statute and could not be punished by a federal court. I can only conclude that the Court's frequently expressed concern with the principles of federalism vanishes when it threatens to interfere with the Court's attainment of the desired result.

Id. at 2108 n.4. Indeed, it frequently appears to do just that.

Similarly, in Roth v. United States, 354 U.S. 476, 504 (1957), Justice Harlan dissented from the Court's decision sustaining a federal anti-obscenity statute (nominally adopted under the postal power) on federalism grounds. Unlike the states, he noted:

Congress has no substantive power over sexual morality. . . . ... [T] dhe dangers of federal censorship in this field are far greater than anything the States may do.

... The danger is perhaps not great if the people of one State, through their legislature, decide that [certain publications are] non-sellable, for the State next door is still free to make its own choice.

Id. at 504-06 (emphasis added).

The same general point was made equally by Justice Brandeis: "It is one of the happy incidents of the federal system that a single courageous State may, if $i t s$ citizens choose, serve as a laboratory; and try novel social and economic experiments without risk to the rest of the country." New State Ice Co. v. Liebmann, 285 U.S. 262, 311 (1932) (Brandeis, J., dissenting) (emphasis added). Thus, federalism ensures that a single state's practice, however unique, will be protected from attempts by the intolerant or the fearful to enforce uniformity upon that state via congressional fiat. 
more localized communities of sentiment that controls, usually just state by state. Pluralism and localized choice, insubordinate to nationalism, in brief, are the residual constitutional rule.

The prerogative of federalism from this perspective is at bottom a prerogative of diversity among state regimes of law and of culture, beyond the veto of others whom it may affront and beyond congressional command for uniformity of beliavior or of law. ${ }^{10}$ The extent of that prerogative, moreover, has nothing to do with the separate limitations thrown onto Congress by the Bill of Rights. Indeed, it antedates the Bill of Rights and in several respects grants greater space than does the Bill of Rights. A significantly refashioned national government came into existence in 1789 with sucli powers as its formulating charter, the Constitution, affirmatively furnished it; but it derived no powers from on higl1 and carried over none from the Articles of Confederation except to the extent they were expressly and affirmatively provided for when ratification of the document enumerating those powers was souglit, in $1787 .{ }^{11}$

Writing of the Constitution for the Supreme Court in 1805, Chief Justice Marshall confirmed this doctrine: "[U]nder a constitution conferring specific powers, the power contended for must be granted, or it cannot be exercised."12 And as Justice Brewer repeated for the Supreme Court in 1907: "[T]he proposition that there are legislative powers . . . not expressed in the grant of powers [to Congress], is in direct conflict with the doctrine that this is a government of enumerated powers." 13

The constitutional assurance of federalism in the sense just described was not left to inference. ${ }^{14}$ Ratlier, an express, precautionary bookend was added to the Bill of Rights to make the matter textually explicit-to designate expressly in whose favor powers not "delegated" to the United States were reserved:

10. See supra note 9; see also Epstein, Self-Interest and the Constitution, 37 J. LEGAL Educ. 153, 155-56 (1987) (arguing that federalism checks sovereignty by allowing states to compete for "residents, businesses, and tax dollars"). Under federalism, the states are constrained in a manner that Congress is not, insofar as each is aware that people may exercise their constitutional right to exit and take up elsewhere. See Edwards v. California, 314 U.S. 160, 173-74 (1941) (state statute criminalizing bringing of nonresident indigents into state an unconstitutional burden on interstate commerce); Crandall v. Nevada, 73 U.S. (6 Wall.) 35, 49 (1867) (implying constitutional right of free interstate movement by overturning state tax on common carrier passengers leaving state). For a recent review of these matters, see McConnell, Federalism: Evaluating the Founders' Design, $54 \mathrm{U}$. CH1. L. REv, 1484, 1491-1507 (1987).

11. Cf. Van Alstyne, Implied Powers, in 2 Encyclopedia of the American Constitution 962-66 (L. Levy, K. Karst \& D. Mahoney eds. 1986) (comparing six different uses of implied powers).

12. United States v. Fisher, 6 U.S. (2 Cranch) 358, 395 (1805).

13. Kansas y. Colorado, 206 U.S. 46,89 (1907).

14. I.e., the inference that what is not affirmatively conferred is impliedly denied (expressio unius, exclusio alterius est). 
The powers not delegated to the United States by the Constitution, nor prohibited by it to the States, are reserved to the States respectively, or to the people. ${ }^{15}$

From 1781 to 1787 , the Articles of Confederation had set the sole terms of national government, in its lesser specifications of weakly enumerated national powers. The felt deficiencies in those enuinerations led to the Annapolis and Philadelphia conventions. ${ }^{16}$ The measures proposed in Philadelphia were proposed to form a more perfect union ${ }^{17}$-a union more perfect to the extent of extending to Congress enumerations of authority it previously lacked. Many subjects (e.g., the divorce or descent laws of the several states) were not in dispute at the time, however, and no proposals were made or adopted to confide any general power to Congress. Nor was this a casual matter at all; rather, it was stressed repeatedly by the Constitution's proponents.

Indeed, the relative proportion of matters left unaffected, even before the addition of the tenth amendment (to settle in whose favor powers not delegated to Congress had been reserved), was stressed by its single most prominent draftsman. It was not in reference to the Articles of Confederation that Madison wrote the followimg assessment and reassurance (as one might otherwise suppose). Rather, he wrote it in respect to the proposed Constitution itself:

The powers delegated by the proposed Constitution to the federal government are few and defined. Those which are to remain in the State governnients are nunierous and indefinite. ${ }^{18}$

15. U.S. CONST. amend. X. In expressly designating in whose favor powers not delegated are reserved, the tenth amendment provides an express federalism marker which ought not be lightly dismissed as merely tautological of the doctrine of enumerated powers. The doctrine of enumerated powers, standing alone, is ideologically indifferent to federalism interests; the tenth amendment is not. To put the same matter somewhat differently, applying the doctrine of enumerated powers with no tenth amendment sense leads one away from the understanding that federalism is not an exercise simply to see how wide one hand (Congress) can be made to swing (through the "interpretation" of its enumerated powers); there is supposed to be another "hand" out there that claps against this hand and not just empty space to be filled up by nationalism. The tenth amendment is a significant counter referent against which the fairness of interpreting enumerated powers may be measured. Its dismissal as a "truism" by Justice Stone in United States v. Darby, 312 U.S. 100, 124 (1941) was more hubris than insight, a refiection of judicial values in the age of the national state.

16. Under the Articles of Confederation, the national government could not exercise control over the states in the essential functions of taxation, regulation of trade or enforcement of treaty obligations. See Notes of Debates in the Federal Convention of 1787 Reported by JAMES MADISON at XVIII (A. Koch ed. 1966); see also id. at 29-30 (remarks of Mr. Randolph, May 29, 1787) (Randolph enumerated five defects of the Articles of Confederation: the Articles granted no authority to (1) prevent or support war, or provide security against foreign invasion; (2) check quarrels between states; (3) provide general benefits, such as the regulation of interstate commerce; (4) defend itself against encroachments of states; and (5) declare itself paramount over state constitutions.).

17. U.S. ConST. preamble (emphasis added).

18. The Federalist No. 45, at 292 (J. Madison) (M. Beloff ed. 1987). 
Thus The Federalist put the basic proposition publicly, in James Madison's essay, ${ }^{19}$ during the ratification debates. Nor was it left in doubt who was expected to make good on this understanding-assuredly not Congress (what an odd Catch-22 that would be), but rather the courts, in the course of judicial review. As Hamilton emphatically put it:

If it be said that the legislative body are themselves the constitutional judges of their own powers, and that the construction they put upon them is conclusive upon the other departments, it may be answered, that this cannot be the natural presumption, where it is not to be collected from any particular provisions in the constitution. ... It is far more rational to suppose that the courts were designed to be an intermediate body between the people and the legislature, in order, among other things, to keep the latter within the limits assigned to their authority. ${ }^{20}$

Accordingly, article III emphasized that the judicial power would extend to all cases "arising under this Constitution,"21 including most prominently ${ }^{22}$ federalism cases, the point being by this means to keep the Congress "within the limits assigned to their authority," 23 and not allow it to presume to the regulation of things not committed to its discretion. Indeed, this was declared as the most important judicial task. ${ }^{24}$

19. Marshall relied heavily on The Federalist, calling it " $a$ work now acknowledged by all to be a clear and a just exposition of the constitution." G. GUNTHER, JOHN MARSHALL's DEFENSE OF McCullocl v. Maryland 194 (1969) (footnote omitted); cf. Hodel v. Virginia Surface Mining \& Reclamation Ass'n, 452 U.S. 264, 307 (1981) (Rehnquist, J., concurring in the judgment) ("It is illuminating for purposes of reflection, if not for argument, to note that one of the greatest 'fictions' of our federal system is that the Congress exercises only those powers delegated to it, while the remainder are reserved to the States or to the people. The manner in which this Court has construed the Commerce Clause amply illustrates the extent of this fiction." (emphasis added)).

20. The Federalist No. 78, at 398 (A. Hamilton) (M. Beloff ed. 1987) (emphasis added); see also McCulloch v. Maryland, 17 U.S. (4 Wheat.) 316, 423 (1819) (Marshall, C.J.) ("[S]hould congress, under the pretext of executing its powers, pass laws for the accomplishment of objects not intrusted to the [national] government it would become the painful duty of this tribunal, should a case requiring such a decision come before it, to say, that such an act was not the law of the land."); 1 A. Beveridge, THE LIFE OF JoHn MARSHALl 452 (1919) (remarks of John Marshall during the Virginia ratiflcation debates) ("If ... [Congress] were to make a law not warranted by any of the powers enumerated, it would be considered by the [National] judges as an infringement of the Constitution which they are to guard. They would not consider such a law as coming under their jurisdiction. They would declare it void." (emphasis in original)).

21. U.S. ConST, art. III, $\S 2$, cl. 1.

22. But see United States v. Carolene Prods. Co., 304 U.S. 144, 152 n.4 (1938), which is fundamentally subversive of this view.

23. The Federalist No. 78, at 398 (A. Hamilton) (M. Beloff ed. 1987); see McCulloch, 17 U.S. (4 Wheat.) at 423 (Marshall, C.r.) (firmly stating Court's obligation to strike down laws not authorized by the Constitution).

24. See supra note 20 and accompanying text; see also 2 Elliot's DeBates 489 (2d ed. 1836) (James Wilson, Pennsylvania adoption debate) ("If a law should be made inconsistent with those powers vested by this instrument in Congress, the judges, as a consequence of their independence, and the particular powers of government being defined, will declare such law to be null and void 
B.

The foregoing introductory review shows very little, I suppose, partly because it is introductory, nothing more. Still, I suggest that rather than being dismissed with the conventional impatience of the wellread sophisticate, it implicitly carries a strong set of incidental propositions with it, including these.

First, it is the likelihood of continuing differences, rather than the unlikelihood of uniformity, that is expected to characterize custom, actual practice and substantive law from state to state, all without recourse to Congress on most matters. Diversity and pluralism are, in short, the suppositions (one may say "the very essence") of federalism. They are its nature, not its aberration, i.e., not a condition which, when it appears, enables Congress to take over the field. To the contrary, the daily fact of such differences reports the proof of federalism. In a sense, it is the measure of the thing itself; and it carries its own kinds of checks.

So, what a legislature in State $A$ has deemed wrongful in State $A$, one ought expect (rather than be surprised) may not be thought wrongful in States $B$ or $C$, either in 1789 or, despite all our migrations, mobility and mass communications, in 1989 as well. So, too, on the great generality of such subjects, ${ }^{25}$ Congress was meant (and was granted) no authority to flatten things out, either to impose its own preference or to impose that common to a majority of the states.

Merely to take a timely example (in light of a recent Supreme Court decision ${ }^{26}$ ), sodomy may still be a crime in State $A$, but not a crime in State $B$-and State $C$ may even have departed so far from the "moralism" (or morality) of State $A$ that within State $C$ discrimination against any person based on their private sexual practices is forbidden, rigidly, as a matter of law.

Similarly, State $A$ may put more of its public resources into state or locally funded education than either State $B$ or State $C$. State $C$ may provide lower tax rates, a more vigorous private sector and better roads. State $B$ may make more expenditures (perhaps because it has more money) for running up-to-date courts, although both its roads and its schools are inferior to those in States $A$ and $C$.

Likewise, in State $A$ the civil rule in negligence cases may continue to stress fault as a predicate for reallocating personal losses. In State $B$, however, fault need not be shown if (but only if) the defendant was en-

..."). For an additional elaboration of the principal point, see Van Alstyne, The Second Death of Federalism. 83 Mich. L. REv. 1709, 1722-33 (1985).

25. See Madison's observation, supra note 18 and accompanying text.

26. Bowers v. Hardwick, 106 S. Ct. 2841 (1986) (upholding Georgia criminal sodomy statute). 
gaged in a hazardous activity. State $A$ rejects that approach, thinking that the degree of hazardousness merely adjusts the standard of care, never anything more. State $C$ cares more than either State $A$ or $B$ for spreading compensation around, even assuming this may mean fewer goods and/or higher prices in some ways, and State $C$, unlike either State $A$ or $B$, has eliminated contributory negligence by the plaintiff as a bar to tort recoveries.

And so on, and so forth, from subject to subject: e.g., very different standards of marriage and divorce, very different laws affecting inheritance and descent, ${ }^{27}$ very different standards for licensing (or no licensing) as a condition of certain kinds of employment, laws fully protecting sexually explicit materials from suppression in some states, ${ }^{28}$ laws to the contrary, from place to place.

Second, it is a given of federalism that these differences may make each state more or less attractive to different people. This merely shows again what federalism means; attractiveness is not anything Congress may use in order to intervene, standardize or complain of how different people respond. Congress has no authority to say that a state failing to criminalize sodomy, for instance, is "morally substandard" vis-à-vis states that do. Indeed, the power to say which is the more moral position

27. In McCulloch v. Maryland, 17 U.S. (4 Wheat.) 316, 423 (1819), Marshall adverted to the doctrine of legislative pretext; in a follow-up essay, he used the law of descents as an example, i.e., if the real object of a federal tax law were to "alter the law of descents" (rather than to raise revenue), the Supreme Court would hold it invalid. G. GUNTHER, supra note 19, at 173; see also United States v. Kahriger, 345 U.S. 22, 38 (1953) (Frankfurter, J., dissenting). Again, if the real object is to accomplish "objects not intrusted to the [Nationall government," e.g., to alter the law of descents, "it would become the painful duty of this tribunal ... to say that such an act was not the law of the land." McCulloch, 17 U.S. (4 Wheat.) at 423. The point is both fundamental and not confined. Suppose Congress disapproves of the criminal law of State $C$, or finds unacceptable the wage rates State $A$ offers teenage employees in part-time work, or thinks the laws of descent in State $B$ unfair (i.e., Congress dislikes whom that law favors although the state law neither denies equal protection nor substantive due process by standards set by the fourteenth amendment). May Congress squeeze commerce, levy special taxes or spend-with-strings-attached to force a change? If it does, should the Court go along? Chief Justice Marshall said that it should not whenever the enumerated power is being "fraudulently" used. G. GuNrHER, supra note 19, at 173. In other words, if Congress's motive is made clear, the Court is obliged to withhold its assistance rather than go along as an accessory-a view that seems eminently correct.

28. For example, "obscene" materials in Oregon are currently protected from blanket prohibition under the Oregon state constitution, OR. CoNST. art. I, $\S 8$, though the Supreme Court declines to protect them from state and federal regulation under the fourteenth or the first amendments. Compare State v. Henry, 302 Or. 510, 525, 732 P.2d 9, 17 (1987) ("We hold that characterizing expression as 'obscenity' under any definition be it Roth, Miller or otherwise, does not deprive it of protection under the Oregon Constitution.") with Miller v. California, 413 U.S. 15 (1973) (reaffirming that obscenity is not constitutionally protected and establishing guidelines for defining obscenity) and Roth y. United States, 354 U.S. 476 (1957) (no first amendment protection from federal regulation of obscene materials) and Alberts Y. California, 354 U.S. 476 (1957) (no fourteenth amendment protection from state laws regulating sale or advertisement of obscene material). 
on such matters (criminalizing sodomy or, in contrast, protecting private choice of sexual intimacy) was not given to Congress at all. And that is precisely the critical point. What constrains the differences among state laws on these matters, rather, are constraints of the following sort: (a) constitutional constraints imposed upon all states by the Constitution; ${ }^{29}$ (b) such separate constraints as may be built into a given state's own constitution; and (c) the constraints imposed as an incident of federalism itself, namely that people can and will move, enter, or exit, if suitably attracted or repelled, as each state has reason to bear in mind.

Consistent with this last check-the "checking effect" of federalism-a state cannot smugly pursue its own agenda as though the state existed in a geographic vacuum, or as though the state were hermetically sealed at its borders. While it may be master within its own house, it is not master over the tenants. Thus, it must measure what it proposes to do by its awareness of the presence of coexisting cultures (i.e., other states) and its awareness of the extent to which people may move out or move in. Federalism checks it in some measure though neither Congress nor the fourteenth amendment may do so in the particular circumstance. Nor-and here's the point-may Congress intervene to check that check. That is the check-that people may vote with their feet, with all that that implies.

We have already noted as an example that in North Carolina sodomy may even now be a crime while in California it is not; and that this is itself merely an example of federalism, i.e., a matter not given to Congress to trench on but a matter reserved to an expected diversity of treatment state by state. ${ }^{30}$ Because the United States is not Balkanized by Berlin Walls, federalism exerts its own leavening constraint on both North Carolma and California. California cannot seal its borders against persons so distressed by its outrageous example of "moral depravity" that they will give up whatever advantages they enjoy there (a good job, a high level of public goods, etc.) and move to North Carolina, taking with them whatever skills and personal property they may possess. And vice

29. E.g., U.S. CONST. art. I, $\S 10$ (no ex post facto laws, no bills of attainder, no laws impairing the obligations of contracts); U.S. CONST. amend. XIV, $\S 5$ (no laws abridging the privileges or immunities of citizens of the United States nor denying equal protection or depriving persons of life, liberty or property without due process, with power vested in Congress to "enforce" these fourteenth amendment restrictions). Compare Katzenbach v. Morgan, 384 U.S. 641 (1966) (Acting under its section 5 power, Congress may prohibit use of English literacy tests not per se disallowed by the fourteenth amendment.) with Oregon v. Mitchell, 400 U.S. 112 (1970) (Congress sustained in disallowing 21 year-old voting requirement in respect to federal elections, but held not to have authority so to act under section 5 in regard to state or local elections.).

30. See, e.g., Bowers v. Hardwick, 106 S. Ct. 2841, 2845 (1986) (sustaining sodomy statute against fourteenth amendment objections, and noting decriminalization of sodomy in nearly the same number of states as those still treating it as a crime). 
versa, of course, for all who find the moral climate in North Carolina so repressive that its other advantages may weigh insufficiently uilder these circumstances. They may prefer the cost of leaving and moving to California because of the greater sense of personal freedom in matters of sexual practice that state provides. North Carolina cannot bar their exit. California cannot intern them or turn them back; in fact, federalism assures all persons of the right to decide for themselves, partly by keeping Congress altogether out. ${ }^{31}$

Third, this is not a perturbation of federalism, i.e., not an event which, by its occurrence, allows Congress to intervene, choose sides on a matter not assigned to it, or make law on sodomy. To think so is to confuse the assumptions of federalism with a limitation on federalism itself, as though federalism "counts" only when it has no material effects. Federalism always had material effects, however, which is why some people rejoice in it and others-those who long for national majority rule on all matters they care about and on which they hope to prevail nationally ${ }^{32}$-do not. Disliking federalism, disliking also its consequences as it constrains their capacity to have their way "cost free" even within the state in which they reside, they turn of course to Congress. And so, what then?

In the example just given, it might be that all states except California have the same criminal sodomy law as North Carolina. The opposite situation might equally apply: North Carolina alone may have retained sodomy as a crime. Either way our illustration works equally well. Under either supposition, the internal rule of the one nonconforming state (let's make it California) may be otherwise regarded as a national outrage. Does it make any difference as to what they (i.e., "the people") of the other states may do? I suggest that it does not, and that Congress has no power to carry into execution their will to burden California's singular choice-a choice that has its own risks ${ }^{33}$-by the enactment of a

31. See, e.g., cases cited supra note 10. Compare Williams v. North Carolina, 317 U.S. 287 (1942) (invalidating North Carolina bigamous cohabitation convictions when state neither challenged nor rejected Nevada court findings of bona fide domicile as basis for divorce decrees granted in that state) with Williams v. North Carolina, 325 U.S. 226 (1945) (North Carolina court may refuse to give full faith and credit to the same Nevada divorce decrees when it explicitly rejects Nevada court findings of bona fide domicile in that state).

32. The point is succinctly stated by Justice Holmes in his dissent in Abrams v. United States, 250 U.S. 616, 630 (1919) ("If you have no doubt of your premises or your power and want a certain result with all your heart you naturally express your wishes in law and sweep away all opposition.").

33. For example, that the attraction provided by California's more sexually permissive criminal laws may draw to it more new residents than California would wish to have, or otherwise affect the character or indeed the economy of California in ways not entirely welcome (though the state nonetheless prefers to live with those risks rather than avoid them by mimicking what other states do). 
national antisodomy criminal law, ${ }^{34}$ much less by a law forbidding the shipment of goods in or out of any state lacking an antisodomy statute. ${ }^{35}$ Similarly, I should think it a joke were the Supreme Court to sustain a federal tax in which the tax rate hinged on whether sodomy was a state crime and therefore was meant merely to carry into execution the national passion that sodomy in California must be stamped out. ${ }^{36}$ Likewise, were Congress to provide that no federal highway assistance (or some other form of federal assistance) shall be available in any state or local government within a state failing to criminalize sodomy (to keep the roads safe from immoral uses?), were the Supreme Court to sustain it-well, what would you think about that?37 Should Congress "find"

34. This should fail on a straightforward application of the enumerated powers doctrine, because there is no enumerated plenary criminal law power vested in Congress.

35. This should fail on any serious application of "pretext" doctrine, although it may actually not fail given the tendencies of the Court. See, e.g., Caminetti v. United States, 242 U.S. 470 (1917) (upholding criminalization of movement across state lines incidental to activity Congress regards as sexually immoral); Champion v. Ames, 188 U.S. 321 (1903) (the Lottery Case) (upholding statute interdicting tickets, which Congress disapproves of on moral grounds, whether or not their possession or use is inoffensive under state law).

36. See, e.g., United States v. Kahriger, 345 U.S. 22, 38 (1953) (Frankfurter, J., dissenting) ("[W] hen oblique use is made of the taxing power as to matters which substantively are not within the powers delegated to Congress, the Court cannot shut its eyes to what is obviously, because designedly, an attempt to control conduct which the Constitution left to the responsibility of the States, merely because Congress wrapped the legislation in the verbal cellophane of a revenue measure." (emphasis added)); see also Minor v. United States, 396 U.S. 87, 98-100 (1969) (Black and Douglas, JJ., dissenting) (criticizing use of federal tax statute to punish traffic of substances illegal under state law); United States v. Constantine, 296 U.S. 287, 294 (1935) ("[A] penalty . . cannot be converted into a tax by so naming it, and we must ascribe to it the character disclosed by its purpose and operation, regardless of name." (footnotes omitted)); Hill v. Wallace, 259 U.S. 44, 66-67 (1922) (tax law intended to coerce compliance of state trade boards and their members is both in purpose and effect a form of unconstitutional regulation); Bailey v. Drexel Furniture Co., 259 U.S. 20, 39 (1922) (the Child Labor Tax Case) (in which even Holmes and Brandeis, dissenters in Hammer v. Dagenhart, 247 U.S. 251, 277 (1918), joined the opinion invalidating a tax law intended by Congress to regulate matters exclusively within state's control). But see United States v. Sanchez, 340 U.S. 42, 44 (1950) (tax not invalid because it affects activities that Congress might not otherwise regulate); United States v. Doremus, 249 U.S. 86, 93 (1919) (announcing reasonable relation test between congressional action and congressional power to tax).

The pretext (or purpose-and-effect) doctrine has been virtually abandoned by the Court on federalism questions, despite its recognition and use in other areas of constitutional law, e.g., the equal protection clause, Washington v. Davis, 426 U.S. 229, $239-45$ (1976), the establishment clause, Wallace v. Jaffree, 472 U.S. 38, 55-56 (1985), and the attainder clause, United States v. Brown, 381 U.S. 437, $441-49$ (1965).

37. This is a reprise of Holmes' own discredited dictum in McAuliffe v. Mayor of New Bedford, 155 Mass. 216, 220, 29 N.E. 517, 517 (1892) ("The petitioner may have a constitutional right to talk politics, but he has no constitutional right to be a policeman."). But see Massachusetts v. Mellon, 262 U.S. 447, 480 (1923) ("[T] obligation but simply extends an option which the State is free to accept or reject.").

In Garcia v. San Antonio Metro. Transit Auth., 469 U.S. 528, 556 (1985), the majority lamely suggests that notwithstanding its decision in that case there may be some state prerogatives beyond congressional direction, such as the selection of a state capitol site. There are two noteworthy fea- 
that people in California lacked equal protection from sodomy (thereby justifying the federal criminalization of such an offense) and should the Supreme Court sustain the act of Congress on that ground, ${ }^{38}$ we would likewise know that federalism is dead.

Suppose in addition that while some people in states other than California may want to go to California because of its unique freedom, others find it intolerable twice over: (a) they find intolerable the fact that California permits private acts of sodomy (they regard it as clearly morally "substandard"); and (b) they find intolerable the marginal threat upon their own moral preferences posed by the possibility that some of their own residents, drawn by California's distinctive freedom, ${ }^{39}$ will pick up and leave, and take their productive skills with them. From their perspective, not only is California acting unacceptably by declining to recognize minimum standards of common sexual decency (namely their own) but worse, California may even tend to prosper economically as a consequence, and at their expense (unless they change their laws which they fiercely do not want to do), as an incident of its perverse attractiveness to people suddenly California-bound. At least now may Congress intervene? ${ }^{40}$

tures of this example. First, note the significant triviality of this limit on congressional power. Second, even this restriction may amount to nothing, given the Court's position on the spending power and federalism, i.e., spending with strings attached. To paraphrase Massachusetts v. Mellon, the power of the state to determine the location of its own capitol is not invaded, since the statute, conditioning the availability of federal assistance, imposes no obligation but simply extends an option which the state is free to accept or reject. Alternatively, to revert to McAuliffe, the state may have a right to determine where its seat of government shall be located, but it has no right to federal funds. The Court's most recent review of this matter leaves the door only slightly ajar. See South Dakota v. Dole, 107 S. Ct. 2793 (1987) (7-2 decision) (sustaining statute withholding federal highway assistance to any state failing to criminalize purchase or possession of liquor by all persons under 21 , despite scope of federal requirement).

38. The appropriate theory of Congress would be that each state has a duty not to deny persons within its jurisdiction that same protection (from sodomy) as others in every other state already receive. Bold, and incorrect, is it not?

Note also how such an "interpretation" of the equal protection clause by Congress would work in the exact opposite case, that is, in the case where sodomy is a crime only in North Carolina and not a crime in any other state, and Congress is "morally outraged" with the North Carolina (rather than with the California) rule. Congress could find that persons in North Carolina are not equally protected in their rights of intimate private conduct as those in other states are protected, and declare the North Carolina statute void pursuant to section 5 of the fourteenth amendment. If one pays no attention to any federalism principles, both of these approaches may work.

39. "Freedom" from one point of view, but "decadence" from the point of view of majorities in all the other states.

40. I trust the point of the example is plain, namely, that an enormous amount of questionbegging analysis has been expended upon demonstrating how Congress must be able to intervene, in order to head off the so-called "race to the bottom." Given the mobility of capital and labor, so this claim holds, the "lowest" standards will tend to control unless Congress intervenes. But whose policy is "low" and whose is "high" depends wholly on one's point of view, as this example is meant to suggest. Principles of federalism recognize the subtlety. Moral totalitarians do not. 
I should think it clear that Congress may do nothing of the sortnothing has occurred sufficient to grant Congress a national veto, pursuant to any power it is assigned. The situation presented here is in no way distinguishable from the most commonplace consequences of everyday federalism in 1789. Indeed, it is exactly the same. Then, as now, differences in legal cultures among the states affected different people differently; the most minuscule differences in state laws-as well as the more significant differences-have always had constraining interstate effects. Federalism takes those effects for granted; indeed, it may be said that federalism depends on them for its own checks and balances. That they "actually" materialize changes nothing. Rather, they are suppositions of federalism, i.e., they go with the territory. The contemplation of those effects (on the loss side) may well constrain the degree of "reform" a zealous state legislature might otherwise adopt, by putting it on notice that it cannot seal its borders against those who may leave or call Congress to its aid to impose its own domestic preference on other states and thus nullify the contrast they provide. Federalism likewise stimulates reform (and puts status quo states to their own test) by making clear that neither can other states move through Congress to cut off that one reform-minded legislature. Federalism leavens and enlivens, whereas the "trump" of Congress flattens out. My point, then, is the rudimentary one. On virtually all of the subjects we have very briefly touched on, Congress was given no trump to play.

Finally, I have chosen this example carefully, thinking that, by making California the experimental (and less criminally repressive) state, and by assigning to it the substantive rule that strikes me as that which is frankly the better rule-such that the reader will want to be skeptical of finding power in Congress to destroy it or effectively make it of no consequence-one may see the federalism value of our Constitution sympathetically even as I do. But I do not want to beg any questions in having proceeded in this manner, nor do I care to trade on today's ideological fashions, for the larger point is too important to be misrepresented in this way. Thus, supposing morality were reversed, and all states save North Carolina repealed their antisodomy statutes and then became (a) morally enraged because North Carolina's "regressive" exceptionality seemed unendurably repressive (to them), and (b) economically alarmed because North Carolina was actually attracting (rather than repelling) people and skills and talent because of its stubborn difference from the rest, the point would be the same. Congress could not constitutionally intervene until such time as an amendment was secured through the requirements of article V, empowering Congress to do so pursuant to that change. Such an amendment-such a federal rearrangement-though perhaps desira- 
ble to some (not including myself), is currently not an available option. I have tried only to show that there is some better explanation due from those who think an amendment unnecessary than the sort of explanation we have generally had.

All laws affect commerce in one way or another. Most laws affect commerce among the states, just as they always have and in some measure always must. Notwithstanding conventional wisdom to the contrary, however, Congress was granted no power to regulate "whatever affects" the movement of people or their goods across state lines-doubtless in ready recognition of what such a (wholly fanciful) grant of power would have implied. Indeed, it is a reasonably safe guess that had any enumerated power been proposed in such terms, the Constitution proposing it would have been rebuffed. And similarly, to construe any power as though it were this one, is a facetious judicial act.

It was Holmes, one of our most nationalist judges, ${ }^{41}$ and not Peckham or Sutherland (two of the more "conservative" judges), who pungently observed: "Commerce depends upon population, but Congress could not, on that ground, undertake to regulate marriage and divorce." 42 And why is that? It cannot be because differences among state laws of marriage and divorce cannot "affect commerce." They obviously do (even as Holmes is quick to say), yet this fact gives Congress no au-

41. See, for example, his opinion for the Court in Missouri v. Holland, 252 U.S. 416, 433-35 (1920) (Congressional act protecting endangered birds pursuant to international treaty upheld over tenth amendment objections). See also his dissent in Hammer v. Dagenhart, 247 U.S. 251, 278-81 (Congress may use commerce clause to regulate intrastate economic activities affecting interstate commerce).

42. Northern Sec. Co. v. United States, 193 U.S. 197, 402 (1904) (Holmes, J., dissenting). For his discussion of legislative pretext, see $i d$. at 411 . Note that some of the strongest statements of disagreement against the centripetal claims of Congress to superimpose regimes of national law through the cellophane wrappers of enumerated powers have in fact come from judges not easily dismissed as "soft" on states' rights. See United States v. Salerno, 107 S. Ct. 2095, 2108 n.4 (1987) (Marshall, J., dissenting) (The federal government lacks constitutional authority to authorize federal detention of persons whose predicted future conduct would not violate federal law.); Perez v. United States, 402 U.S. 146, 158 (1971) (Stewart, J., dissenting) ("Because I am unable to discern any rational distinction between loan sharking and other local crime, I cannot escape the conclusion that this statute was beyond the power of Congress to enact."); Maryland v. Wirtz, 392 U.S. 183, 205 (1968) (Douglas, J., dissenting) ("The Court must draw the "constitutional line between the State as government and the State as trader ... ." (quoting New York v. United States, 326 U.S. 572, 579 (1946) (Frankfurter, J.))), overruled in National League of Cities v. Usery, 426 U.S. 833 (1976), overruled in turn by Garcia v. San Antonio Metro. Transit Auth., 469 U.S. 528 (1985); see, e.g., Roth v. United States, 354 U.S. 476, 504 (1957) (Harlan, J., dissenting) (Opposing as unconstitutional federal anti-obscenity statute nominally adopted under the postal power: "[T]he interests which obscenity statutes purportedly protect are primarily entrusted to the care, not of the Federal Government, but of the States."); United States v. Kahriger, 345 U.S. 22, 40 (1953) (Frankfurter, J., dissenting) ("Congress . . . cannot constitutionally grapple directly with gambling in the States [and] compel self-incriminating disclosures for the enforcement of State gambling laws, merely because it does so under the guise of a revenue measure obviously passed not for revenue purposes."). 
thority to intervene and set a national norm; ${ }^{43}$ the case is the same as in Marshall's example respecting differences in state laws of descent, ${ }^{44}$ a subject similarly not given to Congress to preempt or control. ${ }^{45}$ It should also follow that even if in strict form a regulation adopted by Congress were limited to commerce among the states, it would nonetheless be constitutionally objectionabie on federalism grounds if in fact it were but the means Congress seized hold of in behalf of the same unauthorized end, e.g., to drive out marriages and divorces not comporting with the prevailing congressional taste, despite their compliance with valid (though differing) state laws.

\section{At LaRge in the Cellophane Sea}

Suppose an act of Congress (hereinafter referred to as the Act) was candidly framed as follows:

42 U.S.C. $\S 4327$. The Commerce Clause Regulation of Marital Standards Act.

"AN Act the Purpose of Which is to Preempt State Laws OF MARRIAGE AND DIVORCE BY RENDERING OF NO FORCE AND EFfect ANy State Law Respecting Marriage or Divorce More Permissive Than This Congress Alone Considers Moral."

$\S 1$. Definitions: "Proper" marriages within the meaning of this Act are marriages satisfying the following terms:

(a) Marriage between persons both of whom are at least 21 years of age;

(b) Marriage between persons if but only if (etc.) ....

$\S 2$. Definitions: "Improper" divorces within the meaning of this act are divorces of the following kinds:

(a) Divorce on any grounds other than adultery, desertion or extreme mental cruelty;

(b) Divorce when (etc.) ....

\section{§ 3. Operative Provisions:}

43. See also D. ENGDAHL, Constitutional FEdERALISM 28-29, 122 (1987) (Emphasizing the pointlessness of positing a power in Congress to regulate whatever affects commerce since no such power is-or ever was-vested in Congress; the power is merely to regulate that which is "commerce" and then only insofar as it is commerce with foreign nations or among the several states.).

44. See G. GunTHER, supra note 19 , at 173.

45. In an important way, the enactment of the fourteenth amendment (with its express investment of congressional enforcement power in section 5) italicizes the point stressed in the text. To the extent that certain kinds of state laws are felt to be intolerable to essential concepts of basic fairness, they are forbidden by the fourteenth amendment-and Congress is given express power to enforce the limits against every state. To the extent that they are not thus forbidden, there is no Catch-22 lurking in article I, i.e., no smuggled-in means by which intolerant national majorities may punish nonconformist polities that nonetheless have done nothing to offend the provisions in the fourteenth amendment, article I, section 10, or any other affirmative restrictions elsewhere laid down. 
(a) All persons, partnerships, corporations or other entities or associations engaged in commerce shall require of all employees signed affidavits indicating whether such marriage they have is "proper" according to $\S 1$, and whether such divorce they may have had is not "improper" according to $\S 2$;

(b) No person, partnership, corporation or other entity or association subject to $\S 3($ a) shall put into interstate commerce any goods or services unless the affidavits it has on file confirm that, of those among its employees who are married, all have "proper" marriages according to $\S 1$, and that of those among its employees who are divorced, none have "improper" divorces according to $\$ 2$.

$\S 4$. Sanctions: Any person, partnership, corporation or other entity or association acting in violation of $\S 3$ shall be subject to imprisonment for not less than one year nor more than ten years, a fine of not less than $\$ 10,000$ nor more than $\$ 500,000$, or both.

§ 5. Interpretive Guide: In any case arising under this Act wherein is drawn in question the scope, meaning or proper application of this Act, this Act shall be construed in whatever manner as is most likely to accomplish the objective declared in its preamble.

One needs to take a careful look at this mock act of Congress. It will provide a key as one moves to a description of the constitutional status of federalism today, for the manner in which one sees it rightly adjudicated in the Supreme Court will provide at least one insight respecting a large series of fecleralism issues as they have actually tended to be resolved. We have come to the proverbial fork in the road.

The first point to note is the claim of entitlement made by Congress respecting what it seeks to do; namely, that it is entitled to set the terms of marriage and divorce for all persons who need or desire certain kinds of work. The bill also leaves no doubt of the matter by the forcefulness of its preambular declaration, its choice of descriptive terms (e.g., "proper" marriages, "improper" divorces), and the concluding section as well. It makes a claim of Congress's view of its power to act. It interprets article I, section 8 of the Constitution in the following way:

Congress shall have power to regulate marriage and divorce for all people who need or desire work in firms that provide goods or services for people in other states.

It is this power Congress has exercised or, rather, this porver Congress has claimed.

One way of responding to this claim is to take it at face value and reject it quite effortlessly on the following federalism grounds. "Congress is given no power to prescribe the terms of marriage and of divorce," such an opinion might begin, "either generally or for any particular class." "To sustain this Act:," the opinion might then say, 
we would not need to concede the whole power-which no one including Congress now claims for Congress-but we would need to concede an arbitrary part of it, which we are quite unwilling to do.

Prescribing the terms of marriage and divorce for those engaged by firms in commerce is nowhere among any of the enumerated powers granted to Congress. As an interpretative explication of legislative jurisdiction apportioned by the Constitution between that which is delegated to Congress and that reserved from its control, moreover, the Act frankly makes no sense at all. The Constitution does not apportion legislative jurisdiction this way. We see nothing in the enumerated powers provided in article I or elsewhere that grants Congress more power to hem in one's freedom to marry or divorce by the chance circumstance of working for General Motors rather than for the local grocer or, indeed, not working at all.

Tying the employment eligibility of persons to work for certain firms by a requirement that they forego marriages or divorces Congress disapproves, presumes to locate in Congress a decisional power of marriage and divorce the people reserved to themselves, a power reserved to them subject only to such standards they need satisfy under some set of relevant state law that must itself satisfy the fourteenth amendment, which Congress does not here even purport to enforce. The Act imposes an unauthorized and thus unconstitutional condition on all such persons by declaring them ineligible for a large category of jobs unless they yield to Congress's preference as to what constitutes a "proper" marriage and a "proper" divorce. We hold that it need not be met. No useful distinction exists in this regard whether one holds a job at General Motors or a local store vending homeopathic remedies made wholly from backyard herbs. Congress is given no power on either account to require one to yield to Congress the grounds of divorce or the age one is eligible to marry.

Moreover, the Act is very plain as well as forceful in acknowledging whom it means to regulate and why. It is not any business practice of the firm that Congress is concerned with; it is, rather, the marriage and divorce choices of those who seek work there over whom Congress means to exert effective control. Their relation to the firm engaged in commerce is but the attempted means. As we hold that Congress has no power so to regulate them, we hold also that no firm may be penalized for any failure to accede to the congressional demand that it police marriages and divorces according to Congress's will. ${ }^{46}$

While I think this outcome correct, arguably it is not-not according to conventional doctrine that governs a great deal of judicial review today.

On its face, ${ }^{47}$ the Act frames rules applicable exclusively to conventional business enterprises and not to their employees. Moreover, it

46. Needless to say, a state law forbidding employment discrimination by any firm discharging or refusing to hire any person on grounds of not being "properly" married or on grounds of being "improperly" divorced would be as valid and as enforceable as any other conventional state civil rights law. The employer would have no defense that it was merely complying with federal law.

47. See the Act, $\S 3(\mathrm{a})$, (b). 
presumes to instruct the firms to which it applies solely in respect to their employment policies and not otherwise. Even then, so long as they engage only in local (i.e., intrastate) commerce, they are largely exempt from the Act. The conditions of the Act the affected firms need satisfy are effectively applicable only if the firms wish to participate in "commerce among the several states," and not otherwise. ${ }^{48}$ The Act does not even regulate their employment practices directly, i.e., it does not directly command them whom to employ or not employ; rather, "all" the Act does is to declare what commercial goods and services may and may not be traded across state lines, nothing more. 49 Because the law is no more than a rule prescribing what may and may not seek a commercial outlet outside a given state, it seems squarely to be within the enumerated power delegated to Congress. The power to "regulate," it may be said, is the power to provide the rule by which such commerce as is subject to congressional will shall be governed, and that is all that is involved in this Act and in this case. (There is no requirement, it will be said, that the rule Congress adopts must facilitate, rather than bar, particular commerce; neither is it objectionable because Congress disapproves the employment practice of the producer, rather than the particular goods or services as such. The cases are virtually legion on that point.)

It may be true that the Act is meant to discourage people from acting on the degree of freedom permitted them under some state laws (the preamble so declares) but so what of that? That tends to be true in many cases that have been before the Court, e.g., regulations of minimum employable age where the minimum is similarly higher (as the marriage age set by this Act) than a state regards as quite sufficient for a person to decide such matters for herself but where Congress has thought it better to require such persons to wait-and bans from interstate commerce the goods of any firm unwilling to require her to wait. In all such cases, it is

48. This is not true of section 3(a) because the Act requires compliance with section 3(a) without regard to whether the particular business entity engages in any interstate commerce, but if section $3(b)$ is valid (under the commerce clause), it is easy to see section 3(a) as valid within a conventionally generous construction of the necessary and proper clause, i.e., as a means of ensuring the compliance integrity of section 3(b). Indeed, if section 3(b) is valid, the necessary and proper clause will-under existing case law-at once enable Congress to extend section 3(b) itself to any entity doing strictly intrastate business in order that those furnishing competitive services and goods interstate not be threatened by the "unfair" exemption of local sellers of goods and services from federal business regulations already imposed by Congress. This has been the usual manner in which similar acts of Congress are enlarged in installments, gradually extending "wall to wall," to persons and activities not ever engaged in interstate commerce. Accordingly, in two steps or three steps at most, fulfillment of the candid congressional avowal (stated in the preamble of the Act) will be complete if the Act is itself upheld.

49. The Act is modeled from Champion v. Ames (the Lottery Case), 188 U.S. 321 (1903) and Hammer v. Dagenhart, 247 U.S. 251 (1918). 
plain that Congress does not want the state's view of the matter to be controlling or to be relied upon by the employer or the employee. So Congress discourages people from doing what they are "free" to do under state law, by confining their employment opportunities to businesses not engaged in interstate commerce. Of course, Congress has not presumed to regulate marriage and divorce directly (the state law still controls as to that). Q.E.D., this law can be easily sustained.

Note that if this Act is sustained in these circumstances, much necessarily follows from that course..$^{50}$ It will be a matter of indifference that the Act does not facilitate (rather, it bars) commerce among the states. ${ }^{51}$ It will be of no significance, either, that the act of Congress has no purpose simply and sensibly to dislodge commercially discriminatory or protectionist local legislation ${ }^{52}$ (rather it enacts discriminatory legislation), or to put an end to private monopoly or oligopoly shielded by captive (or indifferent) state law. ${ }^{53}$ Neither will it matter that the legislation at hand is not addressed to stabilizing collapsed national or international markets, ${ }^{54}$ i.e., in no way does it purport to address economic conditions beyond the means of state legislatures to do much about if left alone to confront them. Nor will it matter that it is plainly not an exercise in cooperative federalism, i.e., an act of Congress the operation of which is contingent upon state law, ${ }^{55}$ helpful to each alike according to its terms.

In respect to each of these kinds of acts of Congress, and possibly in respect to some other kinds as well, a power to "regulate commerce with foreign Nations, and among the several States" 56 is both coherent and consistent with federalism (indeed, one may say that this is the nature of the affirmative power actually granted). What is not sensible, however, is

50. Including, not trivially, the creation of the means to extend the Act to businesses not engaged in interstate commerce, under the necessary and proper clause (as discussed supra note 48). Cf. Garcia v. San Antonio Metro. Transit Auth., 469 U.S. 528, 537 (1985) ("[I]t long has been settled that Congress' authority under the Commerce Clause extends to intrastate economic activities that affect interstate commerce.").

51. Cf. Gibbons v. Ogden, 22 U.S. ( 9 Wheat.) I (1824) (preempting state act authorizing commercial navigational monopoly license under federal coastal licensing act providing for freer trade).

52. Cf. Welton v. Missouri, 91 U.S. 275 (1875) (applying "negative voice" of commerce clause to a plainly discriminatory state tax on goods originating out of state).

53. Cf. Stafford v. Wallace, 258 U.S. 495 (1922) (antitrust legislation regulating intrastate activity having impact on interstate commerce held constitutional); Swift \& Co. v. United States, 196 U.S. 375 (1905) (sustaining Sherman Act injunction against price fixing scheme by meat dealers based on "practical" observation that some local activities are an integral part of the "current of commerce").

54. Cf. Wickard v. Filburn, 317 U.S. 111, 115-17 (1942) (sustaining a far-reaching act of Congress nonetheless addressed to this very issue).

55. For example, an act of Congress making it a federal crime to remove a stolen car across state lines, in which the definition of "stolen" is tied to the theft law vel non of the state from which the car is being taken.

56. U.S. CoNST. art. I, $\S 8$, cl. 3. 
to read it as a power that provides: "Congress shall have power to embargo the movement of goods and services from state to state to effectuate whatever policies as it likes and according to such terms as it decrees." 57

\section{Navigating the Cellophane SeA}

As already suggested, ${ }^{58}$ if the Act examined in the preceding section were sustained (and it is easy to see that it might), under existing case law it is clear that Congress may also extend it to provide:

No person, partnership, corporation or other entity or association shall produce any goods or services which compete within any state with such goods and services as are produced by entities themselves subject to section 3(b) of 42 U.S.C. $\$ 4327$, without themselves complying with sections 3(a) and 3(b) of 42 U.S.C. § 4327.

The measure is readily sustainable on the following rationale. Without it, local competitors might be thought to benefit from an unfair advantage over their interstate rivals who already must comply with the original Act. Thus, in order that the efficacy of the original Act not be put at risk, all firms competing in respect to similar goods and services should be made to play by the same rules in terms of whom they may and may not employ. The enumerated power in Congress to do so is the enumer-

57. But see D. ENGDAHL, supra note 43 , at 53,60 (first emphasis added; second emphasis in original):

The Constitution places no limit whatever on the ends Congress may use its enumerated powers as a means to attain.... Exclusions from interstate commerce ... are the simplest illustration of this principle at work. Other illustrations include conditioning federal grants, contracts, or permits, or exemptions from federal taxes, upon the recipients' compliance with stipulations which Congress otherwise lacks power to enforce. The requirements thus attached as conditions need not bear a telic relation to any matter of legitimate federal concern.

D. ENGDAHL, supra note 43, at 53, 60 (first emphasis added; second emphasis in original). Professor Engdahl's analysis would require the courts to sustain the hypothetical Act discussed in this essay. He regards Marshall's own statements on limited proper objectives-the pretext doctrine-as "unfounded," as "error," and as "mischievous." Id. at 52-53. I believe Engdahl may be fundamentally in error. Cf. Steward Machine Co. v. Davis, 301 U.S. 548, 590 (1937) (Cardozo, J.) ("We do not say that a tax is valid, when imposed by act of Congress, if it is laid upon the condition that a state may escape its operation through the adoption of a statute unrelated in subject matter to activities fairly within the scope of national policy and power."). Compare L. TRIBE, AMERICAN CONSTITUTIONAL LAW 311-12 (2d ed. 1988) ("[I]t is now settled that Congress may impose whatever conditions it wishes, so long as the conditions themselves violate no independent constitutional prohibition, on the privilege of producing for, serving customers in, or otherwise 'sitting astride the channels of,' interstate commerce." (emphasis in original)) with id. at 400 ("If tacit postulates of federalism are indeed ingrained in the Constitution, courts are not free to dismiss them out of hand as ghosts or spirits in which no one any longer believes." (emphasis added)). See also A. VAN ALSTYNE, K. KAF.ST \& J. Gerard, Sum \& Substance of Constitutional Law 57 (4th ed. 1986) (suggesting that a broad construction of each enumerated congressional power is warranted only "for accomplishing legitimate objectives for which the power was delegated").

58. See supra note 48 and acconpanying text. 
ated power of the "necessary and proper" clause; 59 though the amended Act reaches some firms not in interstate commerce, it is Congress's not unreasonable view that their inclusion is necessary and proper in order to avoid the practical frustration of the original Act. ${ }^{60}$ Since the "integrity" of the federal regulation might be threatened unless the Act is made embracing, its extension to purely local producers is secure. Correspondingly (and here's the point of course), the real purpose and intended effect of the original Act itself-to disallow marriages and divorces not congenial to the congressionally prescribed standards-will be very greatly extended as well. Nor are we nearly done.

Indeed, under prevailing precedent, ${ }^{61}$ if the original Act and the proposed enlargement just described are both valid, then the Act may also be extended to apply to states as employers and to all of their political subdivisions as employers such that the original object, announced in the original preamble, will be fulfilled completely: no work or job for anyone not marrying or divorcing by the congressionally approved standards can lawfully be provided in the United States. The key, then, must lie within the original case. Decide that case wrongly and all else tends to follow inexorably, quite as a matter of course. Hold against that Act, on the other hand, and all else holds firm as well-the enlargements have nothing to tie onto for support.

In fact, as matters now stand under existing case law, either outcome in the original case readily can be reached, as I am confident any reasonably well-informed reader will know. Interestingly, on the other hand, one may nonetheless think that if the final form of the Act-the form forbidding any employment of any person marrying under the age of twenty-one or divorcing on grounds other than those approved by Congress-had itself constituted the original Act adopted by Congress, so enormous a claim by Congress- to control marriage and divorcemight not be sustained by a majority of the Court even today. If that is so, however, it is not merely curious-i.e., strange-that matters should work in this fashion. It should serve to reinforce the point just made: the first case is in fact the critical case to work on. That case does pose the greater intellectual challenge despite its less extreme reach. As we just noted, the subsequent enlargements have nothing sufficient to tie onto (whether pursuant to the commerce clause or pursuant to the neces-

59. U.S. CoNST. art. I, $\S 8$, cl. 18.

60. See United States v. Darby, 312 U.S. 100, 121 (1941) ("Congress, having . . adopted the policy of excluding from interstate commerce all goods ... which do not conform to the specified labor standards, ... may choose the means reasonably adapted to the attainment of the permitted end, even though they involve control of intrastate activities.").

61. See Garcia v. San Antonio Metro. Transit Auth., 469 U.S. 528, $552-57$ (1985). 
sary and proper clause) if the original Act is not upheld. Uphold the original Act, however, and there is no strong break off point for proposing an adequate constitutional distinction down to and including the final form. The reason is that, all other considerations aside, in sustaining the original Act the Court will already have conceded to Congress the power over marriage and divorce through the terms of employment by interstate firms. Having done so, it lacks any "bright line" basis for constitutional objection against the successive measures Congress puts down in its (inevitable) mosaic of extensions. If this is so, then it ought make little difference whether Congress proceeds in installments, or whether it clips off the larger field in a single, massive stroke.

Some readers might be tempted to finesse the federalism question if the final form were itself the original form of the Act, by holding the Act unconstitutional-but on different grounds than "mere" lack of enumerated power. Rather, they might at once leap over that question in favor of landing on a provision in the Bill of Rights. I, too, have considered that temptation, but I think it is even more useful to consider because of the very strong light it also sheds on the original federalism question as well. To be less obscure about the matter, here is what $I$ have in mind.

If the proposed final form of the Act (the wall-to-wall form) were just boldly thrown down by Congress in the first place, I believe many would at once see a different sort of arguable constitutional defect in the Act: a denial of fifth amendment equal protection of the laws. ${ }^{62}$

Looking at the proposed, full congressional regulation in terms of equal protection, one at once may see that Congress made what may readily strike one as an unfair classification: as between those who need to work and those who need not. First, we note, Congress has not presumed to forbid all persons under twenty-one to marry, ${ }^{63}$ nor has it forbidden anyone to seek a divorce other than on the three stated grounds. ${ }^{64}$ Rather, whether such marriages and divorces lawfully occur will still be a function of state law. All such marriages and divorces as are permitted in many states continue to be valid and recognized. In practice, nonetheless, Congress has put such marriages out of reach only for persons under twenty-one who cannot forego the necessity to work. That, moreover, was exactly its expected impact: to deny them any employment opportu-

62. See Bolling v. Sharpe, 347 U.S. 497 (1954) (finding equal protection component in due process clause of fifth amendment).

63. I.e., it has not made such "marriages" (as defined and aliowed under the otherwise controlling applicable state law) a federal ofiense on the grounds that it regards such marriages as imprudently entered into.

64. One reason it has not done so may be the obvious federalism objection to such a law, which does not presume to regulate commerce at all, let alone commerce among the several states. 
nity if (but only if) they presume to marry contrary to congressional will-and so, too, in respect to the "divorce penalty" aspect of the bill.

Second, by thus effectively reserving only to the more affluent cohorts of American sixteen to twenty-one year olds such legal marriage eligibility as is more generously furnished by state law in many states, Congress has simply wiped out marriage (and certain divorce options) solely for the "working" class. A strongly based, fifth amendment equal protection objection virtually suggests itself. The law discriminates against the less well-to-do, solely according to their need to work, in respect to a matter of no less legitimacy (marriage and divorce) for them than for others not similarly affected by this law, namely, the well-todo. ${ }^{65}$ Q.E.D., this act of Congress is unconstitutional on fifth amendment grounds.

The preceding analysis is tempting, but I think it has a link with the federalism question with which we have been concerned. My point is by this means ultimately to get back to the federalism analysis itself, where the more interesting work remains to be done. Here is why $I$ think the two are linked.

Unless Congress has the constitutionally delegated authority to set a uniform national age for marriage eligibility as such (as I do not understand anyone claims to be the case in the first instance), it is a bit awkward to fault Congress for what it did. It does not have the same legislative power to reach persons not related to interstate commerce as it does with respect to those "involved" in that commerce. It has reached all whom it can reach by that power, and it has reached all of them in exactly the same way, i.e., in the only way it can.

A state, for instance, has an obligation of equal protection only to persons "within its jurisdiction," i.e., in respect to those within its legislative authority to command. That it does not try to extend its legislation to persons not within its legislative authority cannot be used by those subject to its jurisdiction to complain. The appropriate field of equal protection comparison, in short, is never larger than the field within the legislative jurisdiction of the state in question. The same proposition applies in respect to Congress. It is simply irrelevant, therefore, that those outside Congress's control are not regulated in the same way when all those within its control are all being treated alike. No equal protection objection can be structured on such a ground.

65. Cf. Zablocki v. Redhail, 434 U.S. 374 (1978) (invalidating Wisconsin statute requiring state resident to prove ability to continue court-ordered child support payments in order to receive court permission to remarry). 
Actually, however, the fifth amendment equal protection perspective we have been using here turns out to illuminate the original federalism (power in Congress) question as well. For in all of the several preceding paragraphs, notice the characterization of the subject of the Act employed to describe the equal protection claim; insofar as it was successful in identifying the subject for purposes of equal protection analysis, it is successful because it describes that subject in the same way as the first opinion ${ }^{66}$ (holding the act unconstitutional on federalism grounds), i.e., as a "regulation of marriage and of divorce." It did not use the different characterization seized upon by the second opinion, i.e., as (merely) a "regulation of what kind of goods or services are eligible in interstate trade."

Our fifth amendment equal protection argument barged right in by noticing how unequally Congress is treating persons in respect to marriage and divorce. The first opinion similarly "barged right in" by noticing the same thing, albeit for federahism review purposes. The Act, the equal protection argument observed, affects most persons but not all persons over sixteen and under twenty-one. It cuts off from marriage only those, but indeed all of those who, though eligible to marry by state law, will need to work before turning twenty-one. It likewise affects most persons but not all persons in the freedom to divorce. Those plainly unaffected are those and only those who (a) do not anticipate the need to work, and who (b) establish residence in a state whose domestic relations law permits divorce whether or not there is evidence of adultery, desertion or extreme mental cruelty. But as such, it is a rather weak argument because those that slip by the regulation of Congress are merely those who, by stipulation, Congress is not authorized to reach. The federalism argument is, in fact, the better one. It went more directly to the point; it questioned the authority in Congress to reach those whom it presumed to reach in the manner it did. It did not bail them out by merely faulting Congress for failing to reach others as well.

On the other hand, if one characterized the act of Congress differently, as "merely" an act determining the eligibility for certain goods or services to move in interstate commerce-and not as a regulation of marriage or divorce at all-there is hardly any more of an equal protection issue left, any more than there was a federalism issue. All those subject to Congress's power-namely, similarly situated firms, those sending goods and services across state lines-are treated identically; all must comply with the same standards. That Congress does not regulate those who are not employers is irrelevant. That Congress does not presume to

66. See supra text accompanying note 46 . 
regulate employers not engaged in interstate commerce, it may similarly be said, does not deny equal protection to those who are engaged in interstate commerce. That is just how the alternative opinion (sustaining the Act) chose to describe the situation in the manner of characterizing the Act.

The original problem was also "actually" the same problem of correct characterization of the Act for purposes of constitutional review. Where one goes in will measure how one is bound to come out, whether one frames it as an enumerated power question, or as a fifth amendment question. Moreover, I shall insist that it is a problem compelled by the doctrine of enumerated powers (delimited, delegated affirmative powers plus the tenth amendment), and not one we have imagined or contrived.

Examine once again the act of Congress presented in Part II. If asked to answer the following question, what answer are you inclined to provide? (Note how entirely different answers were implicit in the two rival approaches reflected in the earlier discussion of the Supreme Court's treatment, pursuant to the first of which the Act is held invalid and pursuant to the second of which it would be sustained. Which did you think more nearly correct?) Here is that question:

Is this Act a regulation of marriage and divorce or is it a regulation of commerce among the several states?

"Obviously it is at least nominally a regulation of commerce among the several states," one is inclined to say. "Obviously it is also a regulation of marriage and divorce of sorts (albeit admittedly of an odd, nonstandard sort)," one quickly adds. "Obviously, too, Congress does think certain kinds of marriage and certain grounds for divorce are more appropriate than other kinds and other grounds (for it so declared), and Congress obviously means to stop those it deems to be in the latter category so far as it believes it has the power to dc so. All this is clear. So, what's the point?"

In thus answering, one declines to take the question as put. Rather, one denies its "either/or" dichotomy (i.e., the act of Congress is "either" the one thing-which Congress is plainly given power to regulate- "or" that it is another thing-which Congress was not given power to determine). But is the question just an instance of putting a question containing a logical fallacy? For constitutional purposes I think not. Indeed, it is a question never regarded as contrived in other areas of constitutional law. Rather, choosing one or the other kind of characterization, to prevent unconstitutional fraud, is regarded as the most critical task of the judiciary.

Here is a familiar example from a neighboring clause affecting federalism: Was the thing enacted by Congress and held invalid in Bailey $v$. 
Drexel Furniture Co. ${ }^{67}$ (in which Holmes concurred) a "tax" or was it a "regulation"? Note, again, we treat it as though it cannot be both. But it too, you surely should declare, was both one and the other: an exercise of one enumerated power as well as a nonstandard example of another kind of power-one not given to Congress. Quite right, yet consider how the Court answered the question in Bailey itself. They did not answer it as you have just done. They actually presumed to say it was not a "tax," but a "regulation," and then held it unconstitutional. How odd, for without benefit of the opinion-and without the conditioning of one's thinking the case itself provided-I doubt whether one would agree. Or at least one would say that the question as "answered" in Bailey was treated in the same "either/or" (but not both) fashion as I pressed you to do for the question we just now laid aside.

The act in question in Bailey was in form an excise tax: a fiscal levy, payable into the national treasury, incidental to a particular activity insofar as one partook of that activity and not otherwise. In that sense it was. clearly a "tax." If one still insists otherwise, I respectfully suggest some wriggling on one's own part, i.e., one's insistence in describing it as not a "tax" (or not a "true tax," or "not merely a tax") makes an appeal that may be appropriate but requires some explaining along the way. This, of course, is just what the Supreme Court itself did, is it not?

What did the Court do in Bailey, in so characterizing the statute in question-as indeed it characterized it not as a "tax"-and how might a like inquiry be pertinent in our original case as well? Among such additional observations made by the Court in Bailey were observations such as these (why, if at all, did it think them germane?): what effect(s) was the thing-called-a-tax-by-Congress (and on its face indeed a tax) most likely to have, and what effects was it obviously meant to have? Was it clear, under the circumstances, that Congress would in fact be more disappointed were anyone to pay it rather than saving the expense by altogether shifting out of the activity to which the tax was attached? If so, why should it matter? What does it matter why the tax was imposed? Does anything turn on this? Holmes thought so, ${ }^{68}$ Frankfurter thought so, ${ }^{69}$ even now the conventional wisdom says it may be so. ${ }^{70}$ But if anything does turn on it, why?

67. 259 U.S. 20 (1922) (holding unconstitutional an excise tax on net profits received from sale of goods produced by establishments employing anyone under a certain age).

68. See id. at 38 (1922) (Holmes, J., joining majority opinion of Taft, C.J.).

69. Sce United States v. Kahriger, 345 U.S. 22, 38-39 (1953) (Frankfurter, J., dissenting) ("What is relevant to judgment here is that, even if the history of this legislation as it went through Congress did not give one the libretto to the song, the context of the circumstances which brought forth this enactment ... emphatically supports... that what was formally a means of raising revenue ... was essentially an effort to check if not to stamp out professional gambling."). 
The answer is that definitions (including definitions of particular nouns in the Constitution) are slippery sorts of things-a thing may look like a tax, be said (by Congress) to be a tax, have lots of the conventional apparatus, accompaniment, regulations, etc., common to a tax, be payable as a tax-and yet not be a tax at all. So, when is a tax not a tax, for constitutional purposes? When, constitutionally speaking, it is a "regulation" instead. In what sense? In the obvious sense that upon fair examination, it is clear that the predominant objective of the levy upon the taxed activity is to influence those subject to its terms rather than to affect revenue. Yet, unless one imagines that a thing cannot be a "tax" if merely meant to influence the amount of the activity on which it is levied (and who says it cannot?), the situation is no different from the dichotomous question we framed earlier.

What one does in each case is to determine the function of the clause in question and identify the statute according to that match, and then assess the statute's substantive constitutionality accordingly, nothing more and nothing less.

When is a tax not a tax? When, functionally speaking, it is a regulation instead. When is a regulation of commerce not a regulation of "commerce"? When, functionally speaking, it is plain that Congress is indifferent to commerce and concerned, rather, with who is getting married and on what grounds others are getting divorced-matters not entrusted to Congress's will.

The examples can be multiplied and, with the singular exception of the commerce clause, judges and most writers do not take the question or the manner of answering it as either nonsense or as beside the point. To the contrary, they regard it as crucial to meaningful federalism review, exactly as in Bailey itself.

Here is an equivalent example from a neighboring area of constitutional review - the equal protection clause: "When is a regulation of admission by test score not a regulation of admission by test score? When, functionally speaking, it is a regulation of admission by something else, e.g., when it is a regulation by race." 71 And if, functionally speaking, it is a regulation of admission by race, it will be constitutionally examined accordingly and not on some lesser or more naïve basis; otherwise, the equal protection clause becomes a sham.

70. See D. ENGDAHL, supra note 43, at 154. Professor Engdahl approves such thinking and praises Justices Black and Douglas in insisting so, see Minor v. United States, 396 U.S. 87, 100 (1969) (Douglas and Black, JJ., dissenting), though he flatly denies the relevance of the question with respect to "regulations of commerce among the several states."

71. Cf. Washington v. Davis, 426 U.S. 229, 245-48 (1976). 
In turn, what is the resolving device in all such dichotomous characterizations, of which the general form is this: "When is an $X$ not an $X$ ? An $X$ is not an $X$ when functionally speaking it is a $Y$." It is always the same device, whether called the "pretext" rule, "purpose and effect analysis," the "cellophane wrapper doctrine," or "the doctrine of constitutional fraud." Applying it consists, first, in noticing the full effects of the law. Next, one notices too what interests evidently drove this law, i.e., whom it meant to affect, how and why. The inquiry itself yields the description one is thus prepared to provide. That is all one ineans by describing the law as $X$ or as $Y$ "functionally." Or, if one prefers, it is what one means by describing it "an $X$, but an $X$ intended to act like a $Y$, and does act like a $Y$, such that it is examinable for its constitutionality by standards controlling it as a $Y$," nothing more but also nothing less. Alternatively still, one will say: "It comes in the cellophane wrapper of an $X$ but it is a false positive $X$ which will therefore not be credited as an $X$." The locution one selects is, perhaps, unimportant; what is important is to stay alert as a judge.

So, too, exactly in Bailey. And so, too in our case as well. So the question put previously may not be inane and may require an answer: an answer, moreover, one should be equipped to provide. The sole remaining puzzle, then, is how to go about the task of providing it.

The skill necessary to provide it requires a "tenth amendment" sense and an "enumerated powers" sense as well. Without some sense of each-indeed, without some sense of each as informed by some sense of the other-one is at sea in total uncertainty, as inuch so in Bailey as in our immediate case. To put the same matter somewhat differently, obviously one can never know when an $X$ is (functionally speaking) a $Y$ unless one has some delimiting idea of what an $X$ is meant to do-so one can form a firm inpression of when a noininal $X$ is, for constitutional purposes, not an $X$ after all, but just a "false positive $X$," so to speak, or a $Y$ dressed up in drag. In short, unless one has some notion of bona fide function in respect to each enumerated power vested in Congress, including the commerce clause power, one has no useful capacity of judicial review. For necessarily one will be unable to deal with "false positive $X \mathrm{~s}$ " or distinguish unauthorized $Y \mathrm{~s}$ from $X \mathrm{~s}$ in cellophane wrappers. Indeed, one will treat them all just alike.

Students (and a fair number of academics and judges too) have no trouble with this in some areas. They have never failed to see the necessity for this approach in, for example, equal protection cases, in order to keep the Constitution intact. Many also readily see the point in cases such as Bailey, and even agree that that decision was well reached. 
We revert, then, to the commerce clause itself. What range of tasks was assigned for possible national address by delegating to Congress the "power to regulate commerce with foreign nations and among the several states,"72 such that one can know an $X$ when one sees it, but such that one can also know a "false positive $X$ " at the same time?

I have written enough to try to show that there is no more reason to take a tax act of Congress and call it "not-a-tax" than there is to take a regulation of commerce and call it "not-a-regnlation-of-commerce." Both puzzles are driven by exactly the same set of pure, good faith, federalism concerns. And a failure to treat the mquiry with equal weight will necessarily give away to Congress what it was not meant (and was not given power) to have. One must have an idea of what Congress was meant to be able to do by the delegation of power to regulate commerce among the several states-as well as an idea of what it was not meant to be able to do by that means-to make the doctrine of "legislative pretext" work. Exactly the same (no more, no less) is true of each other enumerated power invoked or relied upon by the national government, irrespective of which it happens to be. ${ }^{73}$

From this point of view, even the word "commerce" in article I, section 8 merely presents the same recurring federalism challenge presented even by the easiest "tax" or "treaty" case, consistent with pretext doctrine. So, for example, an act of Congress may be valid to carry into execution the obligations of a "treaty" made "under the authority of the United States," 74 but evidence that the whole thing is a fraud-there is a "treaty" but not a real treaty (i.e., the "treaty" is a charade engineered to create a bootstrap for the congressional act and there were in fact no matters whatever at issue with the nation whose good offices have merely been conscripted for the fraud)-will and must carry its own weight in the Supreme Court. The mask of the false positive "treaty" thus taken away, the act also falls because it has nothing to attach to. Indeed, if it does not fall, i.e., if the Court turns a blind eye and thus colludes with Congress, federalism exists thereafter only in the cellophane wrappers afloat in a national political sea.

The original Act (not just the act in its ultimate, wall-to-wall form) was itself the best test of these things. Was it a regulation of "com-

72. U.S. CONST. art. I, $\S 8, \mathrm{cl} .3$.

73. Here is a good example. "When is a treaty not a treaty?" Answer: when not negotiated in good faith to resolve an issue of shared concern with a foreign nation, but when, rather, unilaterally inveigled just to create a bootstrap for otherwise unauthorized acts of Congress which would then carry the (fake) treaty into effect.

74. See, e.g., Missouri v. Holland, 252 U.S. 416, 433-35 (1920) (holding that acts of Congress, made in pursuance of a treaty, may be valid even if the acts unaided by the treaty would be beyond Congress's power). 
merce" among the several states, or was it (in purpose, in effect, in arrogance, in what it sought, in its tenth amendment disregard) quite something else? I suggest it was rather plainly something else under the hypothesized circumstances, and easily ought to have been struck. But, given today's desuetude on these matters, particularly since Chief Justice Stone's much applauded dismissal of the tenth amendment as mere truism, ${ }^{75}$ one cannot at all be sure. The likelihood is that it might be held invalid even now because its public presumption was so nakedly asserted and its cellophane wrapper not laid on in quite the right way. A different set of recitations (e.g., some convenient "findings" about permissive divorce standards "affecting the national economy"), however, and likely the act might get by.

If this is so, however, it is no exaggeration to suggest that the principal importance of understanding the case law of federalism today is practically confined to specialists employed by Congress: specialists who know best how to navigate the cellophane sea. The political task of forcing each new regime of national law, subject by subject, is largely a task of forbearing from moving all at once (i.e., too obtusely) rather than in increments to which supplements may subsequently be attached, ${ }^{76}$ and in knowing what recitations are appropriate to include with each bill. Between one set of judges one will have reason to believe are likely to prefer the congressional preference refiected in the law (judges predisposed to sustain it against any federalism objection if provided some colorable ground), and one's awareness of other judges who have mistakenly "disciplined" themselves institutionally-i.e., judges who are diffident generally when it is Congress, rather than a state legislature, that makes things up-the remaining task is quite slight: to move by means that seem unegregious at'each step and within cellophane wrappers that past cases provide. In that fashion, the judicial capacity to gain any clear purchase on any seemingly decisive distinction at any particular step is strategically undone. As with Hannibal himself, frustrated by the utter lack of any single clear encounter, ${ }^{77}$ no one case seems significantly different from many others although all (i.e., literally everyone) understand the

75. United States v. Darby, 312 U.S. 100, 124 ("The [tenth] amendment states but a truism that all is retained which has not been surrendered.").

76. A strategy made famous by Fabius (Quintus Fabius Maximus), the Roman general and statesman who avoided the temptation to try to win in a day that which he won by patience, delay and avoidance, over time, through the attrition of an opposing force. It was by this strategy that Fabius, sometimes called Cunctator (the Delayer), defeated Hannibal in the Second Punic War (218201 B.C.).

77. Hannibal of Carthage crossed the Alps to invade Italy in 218 B.C., only to meet defeat at the hands of Fabius, who, as already noted, see supra note 76, wore Hannibal's forces down in a war of attrition. 
point of what is in fact happening. Such dissent as may come from one or two judges in any such case will appear as a mere wail in the wind.

To conclude on quite a different note, however, I suggest that there is nothing inevitable in these matters except so far as the Supreme Court's own practices make them inevitable, because there is in fact nothing distinguishing federalism review from what confronts courts from time to time in every area of judicial review. Our courts periodically confront cellophane wrapped packages in virtually every dimension of constitutional law. ${ }^{78}$ That much is scarcely a matter of surprise, but only that political certainty is a constant. Nothing else need be. It is for the courts themselves to say what shall come of these efforts, i.e., whether they will or will not get by.

We are all aware that state legislatures are occasionally as derisive of establishment clause constraints on their powers, for instance, as Congress often is indifferent in respect to the difference between itself and state legislatures in turn. Like Congress, state legislatures are quick to learn from judicial trends how to wrap legislation in the proper cellophane package. They, too, are fully prepared to move merely step by step. Undoubtedly these efforts sometimes, though not often, succeed. When courts have been attentive the matter does not slide by, and it is these cases, not the (disgraceful) other cases, that have helped turn legislatures back to their proper tasks. ${ }^{79}$ So too sliould it be in respect to Congress.

The critical difference that distinguishes these latter and better cases, moreover, is the difference we have been addressing all along. We have always known what it was. The critical difference is the difference of judicial seriousness in the performance of constitutional review. It is judicial seriousness in federalism review as in all areas of constitutional law that regulates the cellophane sea. Take it away in any area of constitutional law, equivalently as has tended to happen with federalism, and the results would be quite equivalent as well. In the end, the matter is no more arcane than this.

78. See, Lynch v. Donnelly, 465 U.S. 668, 681 (1984) (Christmas nativity scene erected by city as part of holiday celebrations served secular purpose and therefore did not offend first amendment); Plessy v. Ferguson, 163 U.S. 537, 548 (1896) (racially segregated railroad coaches, separate but "equal," did not offend equal protection clause of the fourteenth amendment). Neither refiects well on the Supreme Court itself. Cellophane wrappers, indeed.

79. Compare Stone v. Graham, 449 U.S. 39, 41 (1980) (per curiam) (invalidating Kentucky law requiring posting of copy of the Ten Commandments as without "secular legislative purpose") with Lynch, 465 U.S. at 681; compare Yick Wo v. Hopkins, 118 U.S. 356, 373-74 (1886) (overturning conviction based on discriminatory administration of facially neutral ordinance) with Plessy, 163 U.S. at 548 . 